\title{
Evaluation of the Secretory Immunoglobulin A Levels in the Colostrum and Milk of Mothers of Term and Pre-Term Newborns
}

\author{
Edílson D. Araújo ${ }^{1}$, Ana Katherine Gonçalves ${ }^{1}$, \\ Maria da Conceição Cornetta ${ }^{1}$, Heleana Cunha ${ }^{1}$, \\ Maria L. Cardoso ${ }^{1}$, Sirlei Siani Morais ${ }^{2}$ and Paulo C. Giraldo ${ }^{2}$
}

Federal University of Rio Grande do Norte; Natal, RN; State University of Campinas - UNICAMP2; Campinas, SP, Brazil
Natural feeding constitutes the best form of newborn (NB) alimentation, in view of its nutritional and immunological properties, and its low cost. Maternal milk (MM) is constituted of proteins, lipids, mineral and vitamin elements with adequate quality and quantity for the development of the newborn [1]. In the initial phase of life, human milk (HM) is unquestionably the food that best congregates ideal nutritional characteristics, with adequate nutrient balance, besides offering innumerable immunological and psychological advantages that are important for the reduction of infantile morbidity and mortality [2]. Amongst the immunological properties, MM transfers antibodies,

Received on 12 May 2005; revised 22 August 2005.

Address for correspondence: Dr. Edílson Dias de Araújo. Miguel Castro Avenue, 1525/201 - Lagoa Nova - Natal - Rio Grande do Norte. Zip code: 59.075-740 Phone: (84)32318213/99838961.Fax (84) 32344605. Email: edilsondiasaraujo@bol.com.br.

The Brazilian Journal of Infectious Diseases 2005;9(5):357-362 (C) 2005 by The Brazilian Journal of Infectious Diseases and Contexto Publishing. All rights reserved. defense cells and enzymes, so that breast-fed infants are relatively protected from infectious diseases, which constitute one of the main causes of infantile mortality in developing countries [1]. Maternal milk diminishes the incidence and the gravity of gastrointestinal, urinary and respiratory infections, besides providing a protective effect against bacterial meningitis, botulism, Crohn disease, ulcerative colitis, lymphomas, allergic and other chronic digestive diseases [3]. An ample study of the non-random character of hospitalized preterm newborns indicated that the incidence of necrotizing enterocolitis is significantly lower in those fed with human milk, either exclusively or partially, than in those fed with infant formula [4].

During the decades of 1940 to 1960, there were controversies about the use of maternal versus industrialized milk for preterm newborns, because artificial milk gave the largest weight gains. In the 80's, studies began to show the importance of the preterm newborn mother's milk, particularly during the two first weeks after childbirth, as it contained more calories, a 
greater fat concentration, more protein, sodium and secretory IgA (sIgA) than the milk of newborn term mothers $[5,6]$. Consequently, there was a consensus for the recommendation of the use of the mother's milk to feed the preterm during the first weeks of lactation [3]. Currently, the American Academy of Pediatrics recommends breast feeding during the entire first year of the term newborn's life and recognizes the benefits of human milk for preterm newborn feeding [3]. The metabolic and gastrointestinal immaturity, immunological damage, and associated medical conditions in the preterm newborn can affect nutritional support. Human milk is capable of satisfying the necessities of the preterm and can provide for similar growth rates when compared to term newborns [7]. Human lactation proceeds through three well defined periods: colostrum, intermediate milk and mature milk. Colostrum provides the necessities of the newborn during the first week of life, supplying on average $67 \mathrm{Kcal} / \mathrm{dL}$. It is rich in proteins, minerals and in immunological factors, facilitating Lactobacillus bifidus growth in the gastrointestinal tract and meconium elimination by the newborn [8-10].

The composition of colostrum changes between the sixth and the $14^{\text {th }}$ day of lactation, with a reduction of the concentration of immunoglobulin and proteins and an increase in the lactose levels, fat and energy content, until it has the characteristics of mature human milk [10]. Human milk is divided into two types of elements; these are nutritional factors: proteins (casein, lactoalbumina and lactoglobulina), carbohydrates, fat, minerals, iron, vitamins (B and K), enzymes (lipase and amylase) and disease protection factors: immunoglobulin (IgA, IgM, IgG, IgD and IgE), unspecific defense cells (epithelial cells and macrophages, neutrophils, eosinophils, lymphocytes, and other cells) and immunological factors (bifidus factor, lysozyme, lactoferrin, interferon, complement and lipids) [11]. All five classes of immunoglobulins are present in human milk; they are at higher concentrations in colostrum, constituting a large part of the protein content of this secretion. During lactation, there is a reduction in the concentrations of immunoglobulin; however, the absolute quantity of what is ingested by the child remains unchanged because of an increase in milk volume [12].

IgA type secretory antibodies predominate (SIgA) in human milk; however, they are not absorbed by the newborn gastrointestinal tract. These antibodies protect the infant's mucosal surfaces. Secretory IgA has a peculiar structure that impedes adhesion and posterior establishment of pathogenic microorganisms on the mucous surfaces [13].

Antigens enter in contact with the maternal gastrointestinal or respiratory tract mucous surfaces, where immunocompetent cells are stimulated to produce immunoglobulin, mainly secretory IgA, which is passed on to the newborn by passive immunization or immunity transference $[13,14]$. Due to the immaturity of the immune system, the preterm newborn is more vulnerable to infectious processes, making it dependent on the immunological support provided by breastfeeding.

We examined and compared the levels of total secretory IgA in the colostrum and milk of mothers of preterm and term newborns.

\section{Material and Methods}

This study respected the norms indicated by the "Declaration of Helsinki" (WORLD, 1996) and by Resolution 196/99 of the National Council of Health (BRAZIL, 1996). The spontaneous agreement of the patient was expressed by signature of an informed consent form. This research was approved by the Committee of Ethics in Research of the Januário Cicco Maternity College of the Federal University of Rio Grande do Norte.

\section{Sample processing}

Samples of colostrum and maternal milk were collected by manual expression into empty containers on the $1^{\text {st }}, 4^{\text {th }}, 10^{\text {th }}$ and $15^{\text {th }}$ days of lactation from 20 puerperal women at the Januário Cicco Maternity College. Ten of them were mothers of preterm newborns and 10 were mothers of term newborns. 
After collection, the samples were transported on ice to the laboratory and centrifuged at $1800 \mathrm{X}$ $\mathrm{g}$ for $10 \mathrm{~min}$ at $4^{\circ} \mathrm{C}$ in a refrigerated centrifuge. Three distinct phases resulted: the superior layer contained the lipid portion, the intermediate layer had the liquid (aqueous) phase and the bottom layer was a "pellet", which consisted of the cellular elements of human milk. The lipid layer was removed with the aid of Pasteur's pipette and the liquid phase was divided into aliquots of $1.5 \mathrm{~mL}$ in eppendorf tubes and stored at $-20^{\circ} \mathrm{C}$ until the analyses $[16,13]$. The total secretory IgA was determined by a quantitative radial immunoassay (I.D.R.Q.), using the technique of Mancini et al. (1965), with specific anti-human alpha-chain IgA antibodies (SIGMA). A primary Standard for these assays was made with a pool of colostrums with a known concentration of SIgA of $3.4 \mathrm{~g} / \mathrm{L}$ [13]. These were read on a $1 \%$ agarose gel in PBS $(\mathrm{pH}$ 7.4), with $65 \mu \mathrm{L}$ of anti-IgA human alpha chain antibody incorporated into the $10 \mathrm{~mL}$ of gel on a 8 by $8 \mathrm{~cm}$ glass plate. After solidification of the gel, it was perforated with 25 2-mm diameter holes. Aliquots $(5 \mu \mathrm{L})$ of serial dilutions of the standard, colostrum and human milk were placed in each orifice. The plates were incubated at $4^{\circ} \mathrm{C}$ in a humid chamber for 48 hours. At the end of the incubation period, the plates were stained and the halo diameters determined, to quantify the concentrations of secretory IgA in colostrum and human milk. After incubation, the plates were wrapped with three layers of gauze and washed with saline solution three times, in order to remove the excess protein contained in agarose gel. After the last washing, filter paper was placed on top of the still humid plate and incubated overnight (1618 hours). After this period, the filter paper that covered the plate was removed carefully, humidifying it with salt water. The plate was taken to an oven for complete drying. After that, it was stained with Ponceau "S" solution for 20 minutes and then discolored with distilled water [13]. The data on the colostrum and milk of the 20 women were processed using Graphpad InStat software.

\section{Results}

The levels of total secretory IgA in samples of colostrum and milk of mothers of term newborns varied significantly between the $1^{\text {st }}, 4^{\text {th }}, 10^{\text {th }}$ and $15^{\text {th }}$ days of lactation (Friedman test, $\mathrm{p}<0.0001$ ). The levels of secretory IgA were significantly more elevated on the $1^{\text {st }}$ day when compared with the other days (Wilcoxon test, $\mathrm{p}=0.005$ ); there were higher levels of secretory IgA on the $4^{\text {th }}$ day than the $10^{\text {th }}$ (Wilcoxon test, $\mathrm{p}$ $=0.008$ ) and the $15^{\text {th }}$ day (Wilcoxon test, $\mathrm{p}=0.009$ ). There were no significant differences between the $10^{\text {th }}$ and the $15^{\text {th }}$ day of lactation (Wilcoxon test, $p=0.2026$, Table 1). The levels of total secretory IgA in samples of colostrum and milk of mothers of preterm babies were significantly different between the $1^{\text {st }}, 4^{\text {th }}, 10^{\text {th }}$ and $15^{\text {th }}$ days of lactation (Friedman test, $\mathrm{p}<0.0006$ ). The levels of secretory IgA were significantly higher on the $1^{\text {st }}$ day when compared with the $4^{\text {th }}$ (Wilcoxon test, $\mathrm{p}=0.007$ ), the $10^{\text {th }}$ (Wilcoxon test, $\mathrm{p}=0.005$ ) and $15^{\text {th }}$ day (Wilcoxon test, $\mathrm{p}=0.005$ ).

There were no significant differences between the $4^{\text {th }}$ and the $10^{\text {th }}$ day (Wilcoxon test, $\mathrm{p}=0.1141$ ), between the $4^{\text {th }}$ and the $15^{\text {th }}$ day (Wilcoxon test, $p$ $=0.2411$ ) and between the $10^{\text {th }}$ and $15^{\text {th }}$ day (Wilcoxon test, $\mathrm{p}=0.7671$, Table 2). The levels of total secretory IgA were significantly higher in the colostrum and milk of mothers of preterm newborns, when compared with the levels found in the colostrum of mothers of term newborns (Mann-Whitney test, $\mathrm{p}<0.00001$, Table 3).

\section{Discussion}

The world health organization (WHO) recommends that newborns should be fed exclusively with maternal milk during the first six months of life, and the American Academy of Pediatrics recognizes the benefits of human milk for preterm newborns [15,3]. Industrialized milk formulas can supply the nutritional necessities of preterm and term newborns; however, the protective properties of maternal milk are unique and cannot be reproduced in the laboratory [1]. 
Table 1. Total secretory IgA (mg/dL) by quantitative radial immunoassay in colostrum and milk samples of mothers of term newborns

\begin{tabular}{|c|c|c|c|c|}
\hline \multirow[b]{2}{*}{ Mean \pm sd } & \multicolumn{4}{|c|}{ Lactation days } \\
\hline & $\begin{array}{c}1^{\circ} \\
(2835 \pm 956)\end{array}$ & $\begin{array}{c}4^{0} \\
(129.7 \pm 33.5)\end{array}$ & $\begin{array}{c}10^{\circ} \\
(88.4 \pm 16.5)\end{array}$ & $\begin{array}{c}15^{\circ} \\
(88.4 \pm 16.5)\end{array}$ \\
\hline Minimumvalue & 1,194 & 68 & 63 & 53 \\
\hline Median & 2,831 & 129 & 89 & 75.5 \\
\hline Maximum value & 4,140 & 179 & 114 & 130 \\
\hline \multicolumn{5}{|c|}{$\begin{array}{c}\text { Friedman variance analysis, } \mathrm{p}<0.0001 \\
\text { Wilcoxon Test }\end{array}$} \\
\hline \multirow{6}{*}{\multicolumn{2}{|c|}{$\begin{array}{c}(\text { day } 1) \times(\text { day } 4) \\
(\text { day } 1) \times(\text { day } 10) \\
(\text { day } 1) \times(\text { day } 15) \\
(\text { day } 4) \times(\text { day } 10) \\
(\text { day } 4) \times(\text { day } 15) \\
(\text { day } 10) \times(\text { day } 15)\end{array}$}} & & $p=0.0050$ & \\
\hline & & & $p=0.0050$ & \\
\hline & & & $\mathrm{p}=0.0050$ & \\
\hline & & & $\mathrm{p}=0.0080$ & \\
\hline & & & $p=0.0090$ & \\
\hline & & & $p=0.2026$ & \\
\hline
\end{tabular}

Table 2. Total secretory IgA(mg/dL) by quantitative radial immunoassay in colostrum and milk samples from mothers of preterm newborns

\begin{tabular}{|c|c|c|c|c|}
\hline \multirow[b]{2}{*}{ Mean \pm sd } & \multicolumn{4}{|c|}{ Lactation days } \\
\hline & $\begin{array}{c}1 \\
(23234 \pm 13.6)\end{array}$ & $\begin{array}{c}4 \\
(2283 \pm 3499.7)\end{array}$ & $\begin{array}{c}10 \\
(702.6 \pm 529.2)\end{array}$ & $\begin{array}{c}15 \\
(723.8 \pm 565.3)\end{array}$ \\
\hline Minimum value & 8,855 & 473 & 200 & 143 \\
\hline Median & 21,389 & 813 & 545.5 & 576.5 \\
\hline Maximum value & 46,808 & 11,889 & 1,764 & 2,065 \\
\hline \multicolumn{5}{|c|}{$\begin{array}{c}\text { Friedman variance analysis, } p=0.0006 \\
\text { Wilcoxon Test }\end{array}$} \\
\hline & $\begin{array}{l}(\text { day } 1) \times(d \\
(\text { day } 1) \times(d a \\
(\text { day } 1) \times(d a \\
(\text { day } 4) \times(d a \\
(\text { day } 4) \times(d a \\
(\text { day } 10) \times(d\end{array}$ & $\begin{array}{l}y \text { 4) } \\
10) \\
15) \\
10) \\
15) \\
15)\end{array}$ & $\begin{array}{l}p=0.06 \\
p=0.00 \\
p=0.06 \\
p=0.11 \\
p=0.2 \\
p=0.7\end{array}$ & \\
\hline
\end{tabular}


Table 3. Total secretory IgA concentrations (mg/dL) by quantitative radial immunoassay in colostrum and milk samples from mothers of term and preterm newborns

\begin{tabular}{|c|c|c|c|c|c|c|c|c|}
\hline \multicolumn{9}{|c|}{ Lactation days } \\
\hline & \multicolumn{2}{|l|}{ Day 1* } & \multicolumn{2}{|c|}{ Day 4* } & \multicolumn{2}{|c|}{ Day 10* } & \multicolumn{2}{|c|}{ Day $1^{*}$} \\
\hline & Term & Pre-term & Term & Pre-term & Term & Pre-term & Term & Pre-term \\
\hline Mean & $2,835.6$ & $23,234.3$ & 129.7 & $2,282.7$ & 88.4 & 702.6 & 79.9 & 718.7 \\
\hline$\pm \mathrm{sd}$ & 956.13 & 13,646 & 33.5 & $3,499.7$ & 16.5 & 529.2 & 22.0 & 561.7 \\
\hline Min. & 1,194 & 8,855 & 68 & 473 & 63 & 200 & 53 & 143 \\
\hline Median & 2,832 & 21,389 & 129 & 813 & 89 & 545.5 & 130 & 2,065 \\
\hline Max. & 4,140 & 46,808 & 179 & 11,889 & 114 & 1,764 & 75.5 & 576.5 \\
\hline
\end{tabular}

*Mann- Whitney test $\mathrm{p}<0.00001$; Min. = minimum. Max. = maximum. sd: standard deviation.

Maternal milk contains some defense components, among them immunoglobulin, which has quantitative and qualitative differences when compared with the immunoglobulin in blood serum. Immunoglobulin concentrations are very elevated in colostrum, constituting most of the protein content of this secretion, reaching more than $90 \%$ of the pool protein during the first day of the lactation, decreasing in the next days $[3,16,17]$.

Though the concentrations decrease during the lactation period, the total amount of immunoglobulin ingested by the child practically remains unchanged during the first two to three months of life due to an increase in milk volume [12].

We observed a significant decline in the secretory IgA levels from the $1^{\text {st }}$ to the $15^{\text {th }}$ day of lactation of term newborn breast-feeding and from the $1^{\text {st }}$ to the $10^{\text {th }}$ day of preterm newborn breast-feeding. We believe that the maintenance of elevated levels of secretory IgA in the milk provide by the mothers of preterm newborns due to their need for greater immunological support.

The secretory IgA protects the newborn intestinal mucosa against foreign microorganisms [16]. During infection, SIgA inhibits pathogens from adhering to the mucous, intervenes in bacterial mobility, and neutralizes toxic products. Other mechanisms include elimination of antigens and intracellular viruses by transcytosis [18,
19]. Perhaps the secretory IgA action against infections, mainly diarrheas and colitis, are essential for the immunological protection of newborns, especially in the case of preterm infants.

Various studies have demonstrated that the colostrum and milk produced by mothers of preterm and low-weight newborns have more elevated secretory IgA levels than that of the mothers of term newborns $[20,21]$. Considering that the immunological system is physiologically more immature in preterm newborns, it is possible that the milk and colostrum of the mothers of preterm newborns have higher levels of secretory IgA in order to provide for the necessities of these fragile children. In our study, the SIgA levels in the colostrum and milk of mothers of preterm newborns were higher than for mothers of term newborns, demonstrating an immunological adaptation in lactation for the preterm newborn.

\section{References}

1. Ferreira T.R.B., Rispamonte C., Stella L.C., Albadalejo R.G.C. Imunologia do leite materno. Rev Perspectivas Médicas 1998;9:22-8.

2. Marques R.F.S.V., Lopez F.A., Braga J.A.P. O crescimento de crianças alimentadas com leite materno exclusivo nos primeiros 6 meses de vida. Jornal de Pediatria 2004; 80:99-105. 
3. American Academy of Pediatrics - Work group on breastfeeding. Breastfeeding and the use of human milk. Pediatrics 1997;100:1035-9.

4. Lucas A., Cole T.J. Breast milk and neonatal necrotizing enterocolitis. Lancet 1990;336:1519-23.

5. Goldman A.S., Garza C., Nichols B., et al. Effects of prematurity on the immunologic system in human milk. J. Pediatr 1982;101:901-5.

6. Goldman A.S., Chheda S., Garofalo R. Evolution of Immunologic Functions of the Mammary Gland and the Postnatal Development of Immunity. Pediatric Research 1998; $43: 1-15$.

7. Schanler R.J. Suitability of human milk for the low birth weight infant. Clin. Perinatol 1995;22:207-222.

8. Hartmann P., Cregan M. Lactogenesis and effects of insulin-dependent diabetes mellitus and prematurity. $\mathrm{J}$ Nutr 2001;131:3016-20.

9. Neville M.C. Anatomy and physiology of lactation. Pediatrics Clinics of North America 2001;48:13-33.

10. Nascimento M.B.R., Issler H. Feeding materno: fazendo a diferença no desenvolvimento, saúde e nutrição dos recém-nascidos de termo e pré-termo. Rev Hosp Clin 2003;58:49-60.

11. Cutulo L.R.A., Lamego A.C. Fatores immunologicos da alimentação materno. Arq Catar Méd 1994;23:1918.

12. Chandra R.K. Immunological aspects of human milk. Nutr $\operatorname{Rev}$ 1978;36:265-272.

13. Carbonare S.B., Carneiro-Sampaio M.M.S. Composição do Leite Humano: aspectos immunologicos. In: Rego J.D. Alimentação Materno. Rio de Janeiro: Atheneu 2001.

14. Fagarasan S., Honjo T. Regulation of IgA synthesis at mucosal surfaces. Current Opinion in Immunology 2004;16:277-283.

15. World Health Organization. Report of the expert consultation on the optimal duration of exclusive breastfeeding. Geneva. Switzerland 2002;28-30.

16. Xantou M. Immune protection of human milk. Biol Neonate 1998;74:121-33.

17. Kunzs C., Palmero M.R., Koletzko B., Jensen R. Nutritional and biochemical properties of human milk, Paret II: Lipids, micronutrients and bioactive factors. Clin Perinatol 1999;26:335-60.

18. Russel M.W., Mestecky J. Humoral immune responses to microbial infections in the genital tract. Microbes Infect 2002;4:667-77.

19. Egmond M.V., Damen C.A., Spriel A.B.V., et al. IgA and IgA Fc receptor. Trends Immumol 2001; 22:20511.

20. Barros M.D., Carneiro-Sampaio M.M.S. Milk composition of low birth weight infant mother. Acta Paediatr Scand 1984;73:693-5.
21. Grumach AS, Carmona RC, Lazarotti D, Ribeiro MA, Rozentraub RB, Racz ML, Weinberg A, CarneiroSampaio MMS. Immunological factors in milk from Brazilian mothers delivering small-for-date term neonates. Acta Paediatr 1993;82:289-90.

22. Gross SJ, Walkil S, David RJ, Faix RG, Buckleu R. Elevated IgA in milk from mothers delivering preterm infants. Pediatr Res 1979;13:449. 